\title{
A VIEW ON THE GREEK SHADOW EDUCATION AT THE ERA OF THE ECONOMIC CRISIS. HOW DO PRIVATE TUTORS' WORKING CONDITIONS ARE FORMED?
}

\author{
Chatzidaki Natasha ${ }^{1 i}$, \\ Kyridis Argyris', \\ Kechagias Christos - Thomas ${ }^{3}$ \\ 1Philologist, Md Social Neurosciences, \\ Social Pedagogy and Education, \\ Department of Primary Education, \\ National and Kapodistrian University of Athens, \\ Greece \\ orcid.org/0000-0001-5967-2707 \\ 2Professor of Sociology, \\ Sociology of Education and Research Methods, \\ School of Early Childhood Education (SECEd), \\ Aristotle University of Thessaloniki (Auth), \\ Greece \\ orcid.org/0000-0003-1811-1406 \\ ${ }^{3}$ Laboratory Teaching Staff, \\ Faculty of Primary Education, \\ National and Kapodistrian University of Athens, \\ $\mathrm{PhD}$, Sociology, Philosophy, Culture, \\ MA, Sociobiology, Neurosciences and Education, \\ Greece \\ orcid.org/0000-0001-8302-3555
}

\begin{abstract}
:
Shadow education is regarded by the majority of Greek students as a means to improve their school performance and maximize their chances of admission to higher education institutions. The financial crisis that struck Greece in 2009, has left its marks on all sectors of its economy; employers and employees in shadow education institutions have also been affected to a significant extend. The purpose of this study is to investigate private tutors' working conditions as they have evolved in the period of the financial crisis. It is also examined the engagement of private tutors with financially vulnerable social groups and the degree at which the former alters their financial expectations in order not to exclude the latter from receiving complementary tutoring.
\end{abstract}

i Correspondence: email chatzidaki.natasha@gmail.com 
Keywords: shadow education, shadow education in Greece, shadow education and economic crisis

\section{Introduction}

Primary and secondary education in Greece is free and public with the costs of operating the education system being covered by the state's (Psacharopoulos \& Papakonstantinou, 2005; Zambeta \& Kolofousi, 2014). Its main objective is not only the progress and later the professional and social well-being of individual students but the betterment of the Greek society as whole (Karamarinos, Kyridis, Fotopoulos \& Chalkiotis, 2019). In Greece, receiving some form of complementary, or as more frequently referred to "shadow" education is very common; Greek students receive shadow education in order to improve their school performance and in most cases to enhance their preparation in view of the exams admitting them to state-owned higher education institutions (Giavrimis, Eleftherakis \& Koustourakis, 2018; Kang, 2007; Lee, Kim \& Yoo, 2007) and constitutes a social need (Kelpanidis \& Polymili, 2012). It is not uncommon though nowadays that Greek students often start receiving some form of complementary education since their primary school years, although the attendance to shadow education courses is peaked during secondary education (Kanellopoulos \& Psacharopoulos, 1997).

The financial crisis that erupted in Greece in 2009 (Knight, 2013), is closely linked to the 2008 global financial crisis and has had a profound impact on Greek economy and repercussions on the Greek society undocumented previously for an advanced economy. GDP has declined by 45\% between 2008 and 2015, and unemployment rate peaked at $27,9 \%$ in 2013, with education of young citizens reaching 60\% (Eurostat, 2019). During periods of crises, education is seen not only as a means of securing a job position during times with high unemployment rates, but also as an opportunity for social advancement. Shadow education is also considered as a key of success in competitive examinations of students trying to enter higher education, while being an indicator of social prestige (Kassotakis \& Verdis, 2013).

In many cases students search for private, supplementary education providing additional to the official education (Mori \& Baker, 2010, Buchmann et. al, 2010). This is called "Shadow Education".

Research on shadow education in Greece focuses on the attitudes of school teachers, students and parents towards complementary tutoring (Kelpanidis et al. 2012). It examines the criteria for selecting and changing (Panayotopoulou, 2016), whereas, in the aftermath of the financial crisis, several studies have focused on its impacts on the shadow education stakeholders (Tsikalaki \& Kladi- Kokinou, 2016; Liodaki \& Liodakis 2016). However, more specific questions as the impact of the financial crisis on the working conditions of private tutors and the necessary adjustments they needed to proceed to in order to adapt to the new social and financial regime have not been addressed in the Greek literature. In addition, international studies, despite having studies shadow education, have not systematically studied tutors' attitudes, especially in 
times of financial crises. Therefore, the originality of this paper lies in the investigation of tutors' behaviors in a society severely impacted by an economic breakdown and in studying their financial and social adjustments in relation to both students and private employers. Particular emphasis is given to examining the degree at which actions are taken by tutors in order not to exclude students whose families have been severally impacted by the crises from receiving shadow education, or more generally their social responsiveness.

\section{Shadow education in Greece}

It is a common false conception in Greek society to believe that shadow tutoring is a habit of Greece's educational system only. However, the phenomenon is global (Baker, Akiba, LeTendre, \& Wisema, 2001) with China, Japan and Turkey having the lead (Baker et al., 2001). In Europe, northern European countries have less demand than southern Europe among which Greece holds the lead (Bray M., 2011).

The term Shadow Education encompasses all forms of private additional education provided alongside formal education (Bray, 2011). The Greek terminology for shadow education is Frontestirio and comes from the verb frontizo (= to care). In ancient Greek it meant to contemplate, care for, curate. It is detected by Theogni in the 6th century BC. The word frontestirio in ancient Greece stated the place of study and reflection and has been firstly used by Aristophanes (Babiniotis, 2006; Kechagias, Pappaioannou, \& Antoniou, 2018). At the same time in Greek literature the term para-pedia (Kechagias, 2006; Kechagias, 2009; Bray, 2011; Kassotakis \& Verdis, 2013) is also found, which has a derogatory connotation. The first synthetic word (para-) can mean both parallel education and illegal education activity, against formal education (Giavrimis et al., 2018). Shadow education has existed in Greek society since soon after the creation of the modern Greek state. The way for private education opened in 1844, while the disaster of Asia Minor in 1922, with the arrival of refugees, intensifies social inequalities and increases the demand for higher education (Kassotakis et al., 2013). In 1940, a law establishing formally the shadow education system was passed, which with several amendments, is still in force today (Polyxhronaki 2009). Since then, the shadow education system has been influenced by the numerous educational reforms of the Greek public education system. It is natural that changes in school education, simultaneously affects shadow education, and even considered as often by making it imperative (Zambeta et al., 2014). More specifically, tutoring was considered necessary as long as entries in Greek Universities were limited. It is also considered to be associated with the increase in the intensity of educational inequalities (Hsieh \& Urquiola, 2003; Nambissam, 2012) and competition (Kyridis, 2003). Shadow education functioned - and continues to do so in many cases nowadsays - as means of social mobility (Zambeta et al., 2014). Students used to engage in receiving shadow education mainly during secondary education, and in particular in the last two years of high school, as a mean of obtaining an entry place at their desired university course (Antoninis \& Tsakloglou, 2001). 
At present, shadow education has also become a mainstream choice for parents of students attending primary education. After School Study Centers (ASSC) ${ }^{\text {ii }}$ operate in existing tutoring structures (Karamarinos, et. al. 2019). Their working hours extend from 13:30 until 21:00 and often include creative activities and Saturdays courses. However, it is a fact that they operate without a specific institutional framework that oversees their operation (Laskas, 2014; Dialect, 2017) and there are multiple gaps in the curriculum, labor relations, hygiene and safety of students, workers' rights etc. (Karamarinos, 2019).

The recurring changes in the education system in recent years, have created confusion over the entry criteria in higher education and the key study points that students need to excel at in order to secure an entry place in higher education institutions. This confusion among the Greek society increased the demand for shadow education. For instance, since 1999, the courses on which students are taking to a national level in order to be admitted to higher education have changed five times. The changes relate to the number of courses, the scientific fields for which students can be examined and the course content. The financial crisis in Greece has also led to the creation of Social Tutorials (Koinoniko Frontestirio in Greek) that operate under the auspices of municipalities or churches and provide free support to students whose families cannot afford tuition fees (Zambeta et al. 2014). They belong to the category of solidarity education and accept pupils that meet certain socioeconomic criteria; attendance is compulsory, and nonattendance of students can lead to their expulsion. In these institutions the tutors teach free of charge at their own will.

\section{The Greek financial crisis and Shadow Education}

The economic crisis in Greece with the consequently social crisis (Mylonakou - Keke, 2013) has brought about changes in the entire Greek society, particularly affecting education. Permanent teacher appointments have ceased (Slave, 2014), their teaching hours increased and so did the number of students per classroom (Botou, MylonakouKeke, Kalouri, \& Tsergas, 2017). Public spending on education decreased by $36 \%$ (European Commission, 2016), leading to degradation of the quality of public education. This fact, combined with the general confusion about admission to higher education, has led to a rapid increase of shadow education, which is now often considered mandatory for the successful schooling of Greek students.

The cost of tutoring fees for shadow education that is borne by the students' families (Bray 1999; Schnie-dewind \& Sapon-Shevin, 2012; Zambeta et al., 2014), although

\footnotetext{
ii After School Study Centers (ASSC) were created during the last 5 years by the need for parents to ensure that their children study daily, and because they were unable to control all of their children's work. So, like any other type of full-day, elementary and high school students are transferred from the school environment to a tutorial together with classmates from different classes and a tutor who helps them complete the following day's exercises. Students in this way at the end of the afternoon have studied, solved any questions with their tutor, and returned home to rest. Parents are confident that the child will be prepared for the next day at school, while costs remain lower than private tutoring at home.
} 
reducing, is still particularly high (OECD, 2018) and constitute $3.3 \%$ of the family budget (Zambeta et al., 2014). Students' parents are often unable to cope with the cost of lessons and as a result they either do not choose additional shadow education courses for their children or they stay behind in their payments of tutorial fees accumulating debt (Liodaki et al., 2016). This confirms the sharpening of educational inequalities stemming from the general tendency to privatize education (Hsieh \& Urquiola, 2003; Nambissam, 2012).

At the same time, tutors in the period of financial crisis are complaining about their professional and social rights not being respected. Their hourly wage has been reduced by $48 \%$ and they work for fewer hours than in the past. In addition, in many occasions they work without social insurance and without receiving their legal allowances (OIEEL, 2019). It is therefore observed that although there is an increase in the demand for shadow education in Greece at the time of the economic crisis, the working conditions of the tutors have worsened.

Greek research on shadow education focuses on students' habits and attitudes towards it. They also examine teachers of formal education attitudes on shadow education, first-year students' and secondary school graduates' attitudes on tutoring and its relationship with the family (ESIMPEA, 2008; Veikou, Varesi \& Patouna, 2008; Kelpanidis et al., 2012; Opinion and Market Research Unit, 2012; Panagiotopoulou, 2016; Giavrimis et al., 2018 Sakellariou, 2019). In recent years, research has focused on the impact of the financial crisis on the students' additional educational support options (Tsikalakis et al., 2016) and the extent to which the financial crisis has affected shadow education in total (Liodaki et al., 2016) or more generally the tendency of education privatization in Greece (Karamarinos, et al., 2019). It is found (Chazidaki, 2020) that academic research, although it has focused on the impact of the financial crisis on the institution of shadow education, has not examined the tutors' working conditions per se created by the financial crisis and the adaptation needed.

Bearing in mind all these, it was considered necessary to design and conduct research on the working conditions prevailing in shadow education institutions and the adaptation adjustments made by tutors in the era of the Greek financial crisis. The current paper presents the methodology and findings of this research.

In particular it examines the following as far as shadow education tutors are concerned:

- Have they have been affected financially?

- Do they tolerate to work in adverse conditions without their professional rights being respected?

- Are they being socially sensitive towards vulnerable social groups?

\section{Method}

The present study was conducted in Greece in the Fall of 2019. It involved submissions form questionnaires from tutors who reside in both urban and semi-urban areas of Greece and work in all forms of shadow education. 


\subsection{The research tool}

An original questionnaire was created in electronic form for data collection. It is divided into four sections:

1. Demographic information,

2. A. Scale: Financial adjustments,

2. B. Scale: Adjustments with regard to employers,

2. C. Scale: Social adjustments.

The statements used on the scales resulted from a small pre-research process that was based on discussions with tutors. The statements were then judged by other employees and after the relevant reliability test the three scales were formed.

\subsection{Sample}

The sample of the quantitative research consisted of 120 participants 39 of which $(32.5 \%)$ were male and $81(67.5 \%)$ female. 11 participants $(9.2 \%)$ were under 25 years old, 38 (31.7\%) were $25-30$ years old, 45 (37.5\%) were $31-40$ years old, 18 (15\%) were 41 - 50 years and $8(6.7 \%)$ were over 50 years.

Regarding the professional capacity of the participants, 22 (18.3\%) belonged to the category P04 of the Greek educators (in which Physicists, Chemists, Biologists and IT teachers are included), 19 (15.8\%) were Mathematicians, 17 (12.5\%) were Economists and 64 (53.3\%) were Philologists. 55 (45.8\%) of the participants, held a university degree, 60 (50\%) held a master's degree, and $4(4.2 \%)$ a PhD. In addition, $34(28.3 \%)$ had less than 5 years of service, 43 (35.8\%) had 5-10 years of service, 19 (15.8\%) $11-15$ years and $24(20 \%)$. over 16 years.

Regarding their marital status, 75 (62.5\%) were unmarried, 39 (32.5\%) married with child and $6(5 \%)$ are married without children. As far as their area of residence was concerned 64 (53.5\%) resided in the capital, whereas 56 (46.5\%) resided in other regions. Finally, regarding the origin of the main income in their household, $34(28.3 \%)$ stated that they exclusively provide the main income, $19(15,8 \%)$ stated that they do not provide the main income to their household while $67(55), 8 \%$ ) stated that both they and someone else provide the basic income (Table 1).

Table 1: Sample demographic characteristics

\begin{tabular}{|c|c|c|}
\hline & $\mathbf{N}$ & $\%$ \\
\hline \multicolumn{3}{|l|}{ Gender } \\
\hline Female & 81 & 67.5 \\
\hline Male & 39 & 32.5 \\
\hline \multicolumn{3}{|c|}{ Age (years) } \\
\hline under 25 & 38 & 31.7 \\
\hline $25-30$ & 45 & 37.5 \\
\hline $31-40$ & 18 & 15.0 \\
\hline $41-50$ & 8 & 6.7 \\
\hline Over 50 & 38 & 31.7 \\
\hline \multicolumn{3}{|c|}{ Professional capacity } \\
\hline PE04 & 22 & 18.3 \\
\hline
\end{tabular}




\begin{tabular}{|l|c|c|}
\hline \hline Mathematicians & 19 & 15.8 \\
\hline Economists & 17 & 12.5 \\
\hline Philologists & 64 & 53.3 \\
\hline Education level & \multicolumn{2}{|c|}{} \\
\hline University degree & 55 & 45.8 \\
\hline Master & 60 & 50.0 \\
\hline PhD & 5 & 4.2 \\
\hline Marital status & \multicolumn{2}{|c|}{} \\
\hline Unmarried & 75 & 62.5 \\
\hline Married with child & 39 & 32.5 \\
\hline Married without child & 6 & 5.0 \\
\hline Years of service & \multicolumn{2}{|c|}{} \\
\hline Under 5 & 34 & 28.3 \\
\hline $5-10$ & 43 & 35.8 \\
\hline $11-15$ & 19 & 15.8 \\
\hline Over 16 & 24 & 20.0 \\
\hline Area of residence & \multicolumn{2}{|c|}{} \\
\hline Athens & 64 & 53.5 \\
\hline Semi-urban & 56 & 46.5 \\
\hline Origin of the main income in my household & \multicolumn{2}{|l|}{} \\
\hline Me & 34 & 28.3 \\
\hline Not me & 19 & 15.8 \\
\hline Me and someone else & 67 & 55.8 \\
\hline
\end{tabular}

\subsection{Reliability and internal validity of the tool}

Reliability testing of the factor structures for the three thematic areas was performed by calculating the Cronbach's Alpha index. Reliability refers to the extent a set of variables is consistent with the object to be measured (Hair , Anderson, Tatham, \& Black, 1995). In order to validate the reliability, it was checked whether the Cronbach A values for the three thematic sections are greater than 0.6 which is considered satisfactory (Spector, 1992; Nunally, 1978). In more detail, as shown in Table 2, the Cronbach's Alpha index for financial adjustments was 0.642 , for the thematic section of employer-related adjustments it was 0.651 , and the social adjustments thematic section was 0.654 . The reliability check of all questionnaire statements was 0.651 . The tool was therefore considered reliable.

Table 2: Data Reliability Factor

\begin{tabular}{|l|c|}
\hline Thematic Area & Cronbach's A Index \\
\hline Financial adjustments & 0.642 \\
\hline Employer-related adjustments & 0.651 \\
\hline Social adjustments & 0.654 \\
\hline Total statements & 0.651 \\
\hline
\end{tabular}

\section{Results}

The analysis of the results showed that all three areas under investigation received positive statements. More specifically, as shown in Table 3, the majority of teachers 
admitted that the financial crisis has affected their financial earnings $(\mathrm{M}=2.627, \mathrm{Sd}=$ 1.2040). They tend to vary their rates according to the area where they are teaching $(\mathrm{M}=$ 2.831 , $\mathrm{Sd}=1.2355)$, while also stating that they cannot live exclusively by their own profession as tutors, so they need to work in another field $(\mathrm{M}=3.336, \mathrm{Sd}=1.4973)$.

Table 3: A. Financial adjustments: Mean \& Standard deviation

\begin{tabular}{|l|c|c|}
\hline Statement & Mean & Sd \\
\hline I reduce my course rates because I have fewer students than last year & 3,706 & 1.0444 \\
\hline I need to work in another area in order to cope financially. & 3.336 & 1.4973 \\
\hline I vary my course rates depending on the area of institution or student. & 2.831 & 1.2355 \\
\hline I travel long distances to meet the needs in hours or money. & 3.294 & 1.1376 \\
\hline The financial crisis is responsible for the lower earnings in the teacher industry. & 2.176 & 1.1096 \\
\hline $\begin{array}{l}\text { I have been looking for students in more remote areas because } \\
\text { I think I will be paid more. }\end{array}$ & 3.857 & 1.1881 \\
\hline I take lessons in my own space so that I don't move around and get lower prices. & 3.462 & 1.5227 \\
\hline My average earnings have reduced compared to the pre-crisis ones. & 2.627 & 1.2040 \\
\hline
\end{tabular}

1 = Always, 2 = Frequently, 3 = Sometimes, 4 = Rarely, $5=$ Never

Regarding employer adjustments, as presented in Table 4, most agree that they don't receive the legal allowances (e.g. extra wage during the Christmas, Easter and Summer period, annual leave allowance) from their employers $(\mathrm{M}=2.941, \mathrm{Sd}=1.5038)$. In addition, participants reported working part-time $(\mathrm{M}=3.035, \mathrm{Sd}=1.3438)$, and that were not compensated if they were fired $(\mathrm{M}=3.452, \mathrm{Sd}=1.4823)$. On the contrary, they mostly stated that they were paid extra for their support courses or if they worked more than their scheduled hours $(\mathrm{M}=2.898, \mathrm{Sd}=1.5381)$ and the vast majority stated that they did not accept to work for less money than those legally entitled $(\mathrm{M}=3.439, \mathrm{Sd}=1.3372)$.

Table 4: B. Adjustments with regard to employer: Mean \& Standard deviation

\begin{tabular}{|l|c|c|}
\hline Statement & Mean & Sd \\
\hline I accept to work with less stamps. & 3.134 & 1.4017 \\
\hline I agree to work with fewer or no legal allowances. & 2.941 & 1.5038 \\
\hline I accept to work while my employer declares me to be a different specialty. & 3.838 & 1.3706 \\
\hline I am paid extra for overtime or supportive teaching. & 2.898 & 1.5381 \\
\hline $\begin{array}{l}\text { I help my employer by doing jobs that are not relevant to my subject } \\
\text { without extra pay. }\end{array}$ & 3.974 & 1.2612 \\
\hline I agree to work part time. & 3.035 & 1.3438 \\
\hline I agree to work with less money than legal. & 3.439 & 1.3372 \\
\hline I receive compensation in case of dismissal. & 3.452 & 1.4823 \\
\hline $\begin{array}{l}\text { I agree to teach students of different grades at the same time } \\
\text { in the same classroom so that I do not have to work longer hours. }\end{array}$ & 3.957 & 1.4878 \\
\hline 1 = Always, 2 = Frequently, 3 = Sometimes, 4 = Rarely, 5 = Never & & \\
\hline
\end{tabular}

Regarding the social sector, most stated that they are being informed about the social problems of Greece $(\mathrm{M}=1.636, \mathrm{Sd}=1.0595)$. Still, while claiming that they are not generally adaptable to the prices they will ask for $(M=4.076, S d=1.2065)$, the majority stated that they reduce their rates if the student's family cannot afford the cost of tuition 
$(\mathrm{M}=2.542, \mathrm{Sd}=1.1595)$. They also stated that they reduce their prices if they provide lessons to more than one child of the same family $(M=2.308, S d=1.1631)$. In addition, a relatively important part claimed that they teach free of charge if their students cannot cover the cost of the tuition $(\mathrm{M}=2.059, \mathrm{Sd}=1.2907)$, while they claimed that they teach free or at a low price for their family environment $(\mathrm{M}=2.559, \mathrm{Sd}=1.3110)$. Additionally, most stated that they did not teach in social care entities $(\mathrm{M}=3.847, \mathrm{Sd}=1.2785)$. The majority also reported that they did not give classes aimed at refugee students $(M=3.966$, $\mathrm{Sd}=1.3117)$ and did not teach students from remote areas who do not have easy access to shadow education $(\mathrm{M}=4.026, \mathrm{Sd}=1.3985)$ (Table 5).

Table 5: C. Social adjustments: Mean \& Standard deviation

\begin{tabular}{|l|c|c|}
\hline Statement & Mean & Sd \\
\hline I am informed about social problems. & 1.636 & 1.0595 \\
\hline I teach free students whose family cannot afford. & 2.059 & 1.2907 \\
\hline I reduce my price if I teach more than one child of the same family. & 2.308 & 1.1631 \\
\hline I teach in Social tutoring or volunteering. & 3.847 & 1.2785 \\
\hline I teach children in my family environment for free or with less money. & 2.559 & 1.3110 \\
\hline $\begin{array}{l}\text { I am flexible in negotiating the price regardless of the financial situation of my } \\
\text { students' families. }\end{array}$ & 4.076 & 1.2065 \\
\hline I am reducing my prices due to the financial situation of my students' families. & 2.542 & 1.1595 \\
\hline I am teaching to refugee children. & 3.966 & 1.3117 \\
\hline I teach online classes to students in remote areas who do not have access to teachers. & 4.026 & 1.3985 \\
\hline I = Always, 2 = Frequently, 3 = Sometimes, 4 = Rarely, 5 = Never & \\
\hline
\end{tabular}

To correlate the results with the demographic characteristics of the sample, we performed an ANOVA analysis of variance which indicated that younger tutors, $54.6 \%$ of the age group under 25 years old and $36.9 \%$ of the group 25-30 years old mostly need to work in other sectors to meet their financial needs. The same is true for only $32.7 \%$ of the group over 50 years old. In the same statement, $40 \%$ of unmarried participants, as well as $44.1 \%$ of participants with less than 5 years' experience, are positive. In addition, 54,6\% of PE4 tutors stated that they need to travel long distances to meet their needs in terms of working hours and income, while $41.7 \%$. of Economists was positive in the same statement. Also, $41.7 \%$ of Mathematicians stated that they opt to take courses in their own premises so that they spend less time and money on the move and can provide lower rates for their courses. The level of the participants' education also seemed to play an important role in some of the answers given. More specifically, 59.1\% of participants who hold a university degree stated that they are paid more if they work overtime or take reinforcement courses, while $37.2 \%$ of them said they receive compensation if they are fired. In contrast, $44.1 \%$ of participants with less than 5 years' experience agree to work without their social insurance contribution being fully covered by their employers, while $35.3 \%$ of the same category agree to work while their employer declares them on a different specialty (e.g. administrative positions). Participants who do not provide the main income to their household were positive in the same statement $(33.3 \%)$. 


\section{Discussion}

Shadow education is not a phenomenon that has emerged in recent years (Giavrimis et al., 2018). On the contrary, it has a long tradition in the Greek education system (Polychronaki, 2003). In modern Greek reality, shadow education is influenced not only by government decisions on the formal education, with which it is directly associated, but also by the economic crisis (Liodaki et al., 2016) that Greece has experienced over the last decade (Knight, 2013). Therefore, the purpose of the present study was to investigate the working conditions of teachers working in shadow education during the economic crisis. Research has shown that tutors, in the context of the financial crisis, have become adaptable socially and economically to their changing working conditions. As the financial crisis erupted, tutors' earnings decreased (O.E.C.D., 2017), and they became adaptive in their financial requirements. Younger and inexperienced tutors as well as unmarried teachers cannot make end meet based solely on their work in tutoring. Due to their limited experience (Liodaki et al., 2016) they need to seek additional income for employees in other sectors as they cannot claim better financial deals (OIELLE, 2019). In addition, tutors in the PE04 category, to a greater extent than in other specialties, need to travel longer distances to meet their needs, mainly because of the limited demand for teaching hours courses in their fields (Polyzos, 2019). Thus, they need to seek employment farther than tutor of other specialties, resulting in higher costs in terms of time and money (increased fuel expenses).

The period of the financial crisis has significantly affected shadow education in Greece not only in terms of the number of students, the turnover of courses (Liodaki et al., 2016) and the salaries of tutors, but also in the non-compliance of the legal rights of the latter (OIELE, 2019). The research showed that younger teachers (under 25 years old) mostly agree to work in the same classroom with students of different ages and school years in order to get compensated for fewer working hours. After School Study Centers (ASSC) that have been emerged in Greece in recent years (Karamarinos et al., 2019) opt mostly for younger teachers with little experience (OIEEL, 2019a). In the last decade, Greek tutors have been trying, through trade unions, to claim better working conditions by claiming that employers very often do not proceed to the necessary employee registration with the relevant social security institution, do not cover social fees, or pay they often cover them, and they then require a refund from their employees (Association of Salaried Teachers of Thessaloniki, 2019). The majority of the participants therefore stated that they do not receive the legal allowances from the employer nor the compensation they are entitled to if they are fired. This confirms the violating tutors' professional rights.

The tutors argued that they were interested in the social problems of Greece. The participants mostly stated that although they are not flexible in negotiating the price regardless of the financial situation of their students' families, they reduce their tutoring fees if their tutors cannot cover the tuition. Most importantly, a large part said that they teach free of charge students who cannot afford the cost of tuition. By the above, it is 
evidenced that Greek tutors working in shadow education, , not only do not abandon their educational work during the economic crisis, as is often the case in other Western countries (Day \& Gu, 2010), but they try to provide students from income families with fair educational opportunities (Mylonakou - Keke, 2013). They choose to sacrifice a percentage of their salary, teaching in some cases for free during a harsh period for the Greek society, depicting their interest in the social well-being of students and providing fair educational opportunities for them. Education has been shown to be a means of social mobility (Zeng, 1999 ; Mylonakou - Keke, 2015) that provides trainees with social and economic well-being (Hess, 2004). Shadow education is a key success factor in the educational process (Giavrimis et al., 2018; Glass, 1954) as students' participation in it significantly contributes to their success in entrance exams in higher education institutions (Baker et al., 2001; Bray, 2003). Although the social role of formal education teachers has been systematically investigated (Fredriksen \& Rhodes, 2004), the present research also highlighted the social role of tutors. The free courses, which they say deliver in conjunction with the flexibility in their financial requirements from families of economically disadvantaged students, are designed to help students achieve their educational goals and claim a position in higher education. They strive for their students to achieve sustainable development through education with the ultimate goal of personal and social well-being (Mylonakou-Keke, 2013).

In conclusion, although tutors are particularly affected by the financial crisis, they exhibit extremely high levels of sensitivity to vulnerable social groups in Greece, acting altruistically to contribute to the social well-being of their students. Therefore, the financial crisis, with the ensuing social crisis, imposed changes not only on the financial conditions of tutors but also on their way of thinking and the way they handle their educational work.

\section{Conflict of Interest Statement}

The authors have no conflicts of interest to declare.

\section{Acknowledgement}

All co-authors have seen and agree with the contents of the manuscript and there is no financial interest to report. We certify that the submission is original work and is not under review at any other publication.

\section{About the Authors}

Natasha Chatzidaki holds a Bachelor's Degree in Philology with a specialization in Classical Philology from the National and Kapodistrian University of Athens and a MSc Social Neurosciences, Social Pedagogy and Education at the Department of Primary Education of the National and Kapodistrian University of Athens. She currently works as a teacher of secondary education in private schools.

Dr. Argyris Kyridis is a Professor of Sociology at the School of Early Childhood Education, Aristotle University of Thessaloniki. His research interests focus on Sociology, 
Sociology of Education, Sociological Theory, Quantitative Social Research, and Qualitative Social Research.

Dr. Christos Kechagias works as a teaching stuff laboratory in the School of Education at the National and Kapodistrian University of Athens (Greece). He holds a Ph.D. in Philosophy and Social Sciences and he has studied (M.A.) Sociobiology, Neuroscience \& Education and Post-Doc in Creative Thinking. His publications consist of books and articles on Philosophy, Theory and Epistemology of Education.

\section{References}

Antoninis, M., \& Tsakloglou, P. (2001). Who benefits from public education in Greece? Evidence and policy implications. Education Economics, 9(2), 197-222.

Babiniotis, G. (2002). Dictionary of modern Greek language. Athens: Center for Lexicology, 250.

Baker, D. P., Akiba, M., LeTendre, G. K. \& Wiseman, A. W. (2001). Worldwide Shadow Education: Outside- School Learning, Institutional Quality of Schooling, and Cross-National Mathematics Achievement. Educational Evaluation and Policy Analysis, 23(1), 1-17.

Baker, P., Akiba, M., LeTendre, K., \& Wisema, A. (2001). Worldwide shadow education: Outside-school learning, institutional quality of schooling, and cross-national mathematics achievement. Educational Evaluation and Policy Analysis, 23(1), 1-17.

Ball, S. J. (2007). Education Plc. Private Sector Involvement in Public Sector Education. London: Routledge.

Botou, A., Mylonakou-Keke, I., Kalouri, O., \& Tsergas, N. (2017). Primary school teachers' resilience during the economic crisis in Greece. Psychology, 8(01), 131.

Bray, M. (1999). The shadow education system: private tutoring and its implications for planners. Paris: UNESCO International Institute for Educational Planning (IIEP).

Bray, M. (2003). Adverse effects of private supplementary tutoring: dimensions, implications, and government responses. (Ethics and Corruption in Education series). Paris: IIEPUNESCO.

Bray, M. (2011). The Challenge of Shadow Education: Private tutoring and its implications for policy makers in the European Union. NESSE for the European Commission. Brussels: Directorate - General for Education and Culture.

Chatzidaki A. (2020). Shadow education in Greece in times of economic crisis from the side of tutors' social pedagogical adjustments. (Master Thesis, National and Kapodistrian University of Athens, Greece). Retrieved in March 102020 from https://pergamos.lib.uoa.gr/uoa/dl/object/2897775 (in Greek)

Chatzidaki, N., \& Kechagias, C. T. (2019). Can We Teach Creativity? Extending Socrates's Criteria to Modern Education. The Journal of Aesthetic Education, 53(4), 86-98.

Day C. \& Gu Q. (2010). The New Lives of Teachers, London: The Routledge 
European Commission. (2016). GREECE: Economy shows some resilience in face of capital controls. Brussels: Member States Annual Report Greece.

Eurostart. (2019, Máıos). Eurostart Income poverty statistics. Retrieved in December 12 2019, from https://ec.europa.eu/eurostat/statisticsexplained/index.php?title=Income poverty statistics\&oldid=440992\#At-risk-ofpoverty rate and threshold

Fredriksen, K., \& Rhodes, J. (2004). The role of teacher relationships in the lives of students. New directions for youth development, 2004(103), 45-54.

Giavrimis, P., Eleftherakis, T., \& Koustourakis, G. (2018). An Approach of Shadow Education in Greece: Sociological Perspectives. Open Journal for Sociological Studies, $2,71-82$.

Gillborn, D. \& Youdell, D. (2000). Rationing Education: Policy, Practice, Reform and Equity. Buckingham: Open University Press.

Glass, V. (1954). Social Mobility in Britain. London: Routledge and Kegan Paul.

Hair, F., Anderson, R., Tatham, R., \& Black, W. (1995). Multivariate Data Analysis with Readings. London: Prentice-Hall International.

Hellenic Federation of Private Educational Officers of Greece (O.I.E.L.E.) (2019 a). After School Study Centers operate in buildings - warehouses and in dramatic hygienic conditions. $\quad$ Retrieved November 5 2019, from https://www.alfavita.gr/ekpaideysi/242117 oiele-se-ktiria-apothikes-kai-sedramatikes-synthikes-ygieinis-leitoyrgoyn-ta (In Greek)

Hellenic Federation of Private Educational Officers of Greece (O.I.E.L.E.) (2019 b). Medieval and Employer Brutality: Provocative caregivers call on their hourly wage of $€$ 3.50 for teachers! Retrieved in December 5 2019, from

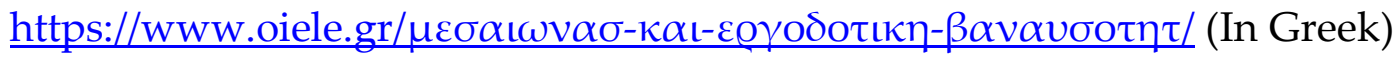

Hess, F. (2004). What is a "public school"? Principles for a new century. Phi Delta Kappan, 85(6), 433-439.

Hsieh, C. T. \& Urquiola, M. (2003). When Schools Compete, How Do They Compete? An Assessment of Chile's Nationwide School Voucher Program. Cambridge, MA: National Bureau of Economic Research

Kanellopoulos, C., \& Psacharopoulos, G. (1997). Private education expenditure in a "free education" country: The case of Greece. International Journal of Educational Development, 17(1), 73-81.

Kang, C. (2007). Does money matter? the effect of private educational expenditures on academic performance: Evidence from exogenous variation in birth order. (Working Paper No. 0704). National University of Singapore. Retrieved in 2 January 2020, from http://www.fas.nus.edu.sg/ecs/pub/wp/wp0704.pdf

Karamarianos, G., Kyridis, A., Fotopoulos, N., \& Chalkiotis, D. (2019). Public school in Greece. Aspects and Trends of Emerging Privatization. Retrieved on December 5 2019, from $\quad$ https://www.alfavita.gr/sites/default/files/2019-

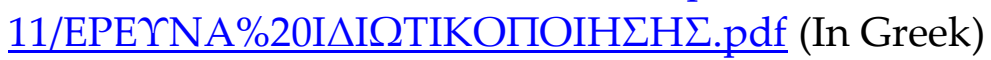


Kassotakis, M., \& Verdis, A. (2013). Shadow Education in Greece. бто M. Bray, E. Mazawi, \& G. Sultana, Private Tutoring Across the Mediterranean. Comparative and International Education (A Diversity of Voices) (p. 93-113). Rotterdam: Sense Publishers.

Kechagias, C. T., \& Antoniou, A. S. (2019). Goddess Athena as leader and mentor in Homeric epics. In Women, Business and Leadership (pp. 106-121). Edward Elgar Publishing.

Kechagias, C., Papaioannou, G., \& Antoniou, A. (2018). In Clouds (Nubes) of Aristophanes, Socrates appears as a sophist school owner, the Phrontisterion ('thinkery'), in which he hosts students of all ages, in order to teach them not only philosophy, literature, physics but also effective sophistic techniques. Dramaturgias, 7, 512-527.

Kechagias, C. T., Papaioannou, G., \& Antoniou, A. S. Ideias e Críticas. Retrieved 2021/01/25,fromperiodicos.unb.br/index.php/dramaturgias/article/view/9426/832 $\underline{8}$

Kechagias, C. (2009). On the nature of position. Athens: Herodotos.

Kechagias, C. (2006). Operational principles and Social structure of the Greek culture. Athens: Atrapos.

Kelpanidis M. Polymili K. (2012). The prevalence of tutoring and the depreciation of the school in Greek education: Survey of pupils who attend shadow education in urban and semi-urban areas of Thessaloniki. Nea Pedia, 1-24 Retrieved in January 6 2020, from http://www.neapaideia-glossa.gr/pdf (In Greek).

Knight, D. M. (2013). The Greek economic crisis as trope. Focaal, 2013(65), 147-159.

Kyridis, A. (2003). Inequality in Greek education and access to university (1955-1985). Athens: Gutenberg (In Greek)

Lee, J., Kim, Y. \& Yoon, C. (2004). The Effects of Pre-class Tutoring on Student Achievement, Challenges and Implications for Public Education in Korea. KEDI Journal of Educational Policy, 1(1), 25-42.

Liodaki, N. and N. Liodaki (2016). Some Effects of the Economic Crisis on Shadow Education in Greece, paper presented at the International Conference in Contemporary Social Studies, Retrieved in September 12 2019, from http://icconss.soc.uoc.gr/en/papers/item/193-some-effects-of-the-economic- crisison-shadow- education-in-greece.html.

Mori, I., \& Baker, D. (2010). The origin of universal shadow education: what the supplemental education phenomenon tells us about the postmodern institution of education. Asia Pacific Education Review, 11(1), 36-48. doi:10.1007/s12564-009-9057-5

Mylonakou-Keke, I. (2013). Social Pedagogy: Theoretical, epistemological and methodological dimensions. Athens: Diadrasi (In Greek).

Mylonakou-Keke, I. (2015). 1844-2014: 170 years of social pedagogy - Can Greece's economic crisis highlight the potential of social pedagogy? International Journal of Social Pedagogy - Special Issue 'Social pedagogy in times of crisis in Greece', 4(1) 5-26. 
Nambissam, G. B. (2012). Private Schools for the Poor: Business as Usual? Economic and Political Weekly, 47(41), 51-58.

Nunally, J. (1978). Psychometric Theory. New Delhi.: McGraw-Hill.

OECD. (2018). Education for a bright future in Greece. Organization for economic, Retrieved in March 122020 from https://www.oecd-ilibrary.org/docserver/9789264298750en.pdf?expires=1584824414\&id=id\&accname=guest $\&$ checksum $=99815432314 \mathrm{FEC}$ 87C6E11FCFC481F28A

Organisation for Economic Co-operation and Development (O.E.C.D.) (2017). O.E.C.D Indicators. Education at a Glance 2017. Paris: O.E.C.D Publishing.

Panagiotopoulou, K. (2016). Students' view of the institution of tutoring and its impact on learning and teaching mathematics in the classroom. (Master Thesis, National and Kapodistrian University of Athens, Greece). Retrieved in December 5 2019, from https://pergamos.lib.uoa.gr/uoa/dl/frontend/el/browse/1317618 (In Greek)

Polychronaki, M. (2004). Educational mobility and training mechanisms. Student and public teacher assessments of the role of tutoring and special lessons in the transition from secondary to tertiary education (Master Thesis, University of Crete, Greece) Retrieved in December 6 2019, from https://elocus.lib.uoc.gr/dlib/f/7/f/metadata-dlib2004polychronaki.tkl\# (In Greek)

Polychronaki M. (September 2009). Shadow education: an unmatched institution of transcending university education systems. Retrieved in October 6 2019, from http://www.eriande.elemedu.upatras.gr/eriande/synedria/synedrio4/praktika1/p olyxronaki.htm (In Greek)

Polyzos A. (May 2019). An analysis and proposal for the IP04 industry over-numbers. Retrieved in November 7 2019, from alfavita.gr: https://www.alfavita.gr/ekpaideysi/287543 mia-analysi-kai-mia-protasi-gia- tisyperarithmies-toy-kladoy-pe04 (In Greek)

Professional Association of Secondary Education Tutorial Owners (2008). Attitudes and habits towards tutoring and private lessons, Retrieved in 4 May 2019 from https://slideplayer.gr/slide/1895964/ (In Greek)

Psacharopoulos, G., \& Papakonstantinou, G. (2005). The real university cost in a "free" higher education country. Economics of education review, 24(1), 103-108.

Sakellariou, N. (2019). Investigation of the tutorial choosing process with a quantitative approach. (Master Thesis, University of Macedonia, Greece). Retrieved in November 7 2020, from https://dspace.lib.uom.gr/handle/2159/23382?mode=full (In Greek)

Salaried Teachers' Association of Thessaloniki (February 2019). Shadow education owners want slaves tutors. Retrieved in December 5 2020, from

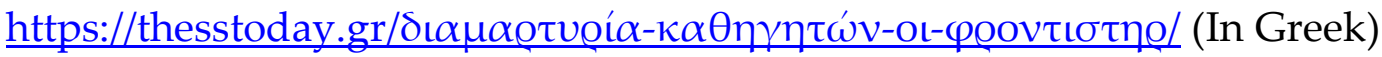

Schniedewind, N. \& Sapon-Shevin, M. (2012). Educational courage: Resisting the ambush of public education. Beacon, MA: Beacon.

Spector, P. (1992). Summated rating scale construction: An Introduction, in Quantitative Applications in the Social Sciences. Beverly Hills CA: Sage. 
Stefanopoulou, S., Kechagias, C. T., \& Malafantis, K. D. (2021). Education in Fictional Dystopian Societies: The Case of Veronica Roth's "Divergent". Journal of Advances in Education Research, 6(1), 49.

Stefanopoulou, S., \& Kechagias, C. (2018). Improving the educational practice using simulations in science education. The contribution of Althusser's theory on the cognitive procedure. European Journal of Education Studies, 4(3), 61-78.

Tzani, M., \& Kechagias, C. (2009). The guide and the mentor. Meri M. Promoting Teacher Education-From Intake system to teaching practice, 35-46.

University Research Institute (2012). Measuring attitudes of tutoring users in Attica. Investigation on behalf of the Athens Chamber of Commerce. Retrieved January 12 2020, from www.sefa.edu.gr/files/sefa ereuna 2012.ppsx (In Greek)

Veikou C., Varesi E., Patouna A. (2008). Pedagogical Context: Study Content and Teaching Practice. In Gilezi V. Quality in Education: A Survey on the Evaluation of Quality Characteristics of the Primary and Secondary Education System (p. 89 - 196). Athens: Pedagogical Institute (In Greek).

Zambeta, E., \& with the assistance of Asimina Kolofousi (2014). Education and Social Solidarity in times of Crisis: the case of voluntary shadow education in Greece. Education Inquiry, 5(1), 24058.

Zeng, K. (1999). Dragon gate: competitive examinations and their consequences. London: Cassell.

Ziontaki Z. (2019). The educational choices of families during the period of the economic financial crisis: the educational "path" of the students and their families from the kindergarden to the university (PhD Thesis, Aristotle University of Thessaloniki, Greece). Retrieved in January 2 2020, from https://www.didaktorika.gr/eadd/handle/10442/46445 (In Greek). 

will be applied to their work. Under the terms of this license, no permission is required from the author(s) or publisher for members of the community to copy, distribute, transmit or adapt the article content, providing a proper, prominent and unambiguous attribution to the authors in a manner that makes clear that the materials are being reused under permission of a Creative Commons License. Views, opinions and conclusions expressed in this research article are views, opinions and conclusions of the author(s). Open Access Publishing Group and European Journal of Education Studies shall not be responsible or answerable for any loss, damage or liability caused in relation to/arising out of conflicts of interest, copyright violations and inappropriate or inaccurate use of any kind content related or integrated into the research work. All the published works are meeting the Open Access Publishing requirements and can be freely accessed, shared, modified, distributed and used in educational, commercial and non-commercial purposes under a Creative Commons Attribution 4.0 International License (CC BY 4.0). 